\title{
Nitrogen balances and losses on intensive dairy farms
}

\author{
S.F. LEDGARD ${ }^{1}$, J.W. PENNO ${ }^{2}$ and M.S. SPROSEN ${ }^{1}$ \\ ${ }^{1}$ AgResearch, Ruakura Research Centre, Private Bag 3123, Hamilton \\ ${ }^{2}$ Dairying Research Corporation, Private Bag 3123, Hamilton
}

\begin{abstract}
Nitrogen (N) balances were constructed for "average" dairy farms in New Zealand, south west England and The Netherlands, and for Dairying Research Corporation (DRC) farmlets varying in stocking rate and use of $\mathrm{N}$ fertiliser and maize grain. $\mathrm{N}$ surpluses were calculated to indicate the potential impact on the environment and these were compared with measured $\mathrm{N}$ losses from the DRC farmlets. On the average New Zealand farm, annual $\mathrm{N}$ inputs of $186 \mathrm{~kg} \mathrm{~N} / \mathrm{ha} /$ year (mainly from $\mathrm{N}_{2}$ fixation) resulted in $\mathrm{N}$ outputs in milk+meat of 55 $\mathrm{kg} \mathrm{N} / \mathrm{ha} /$ year (30\% efficiency) and a $\mathrm{N}$ surplus of $131 \mathrm{~kg} \mathrm{~N} /$ ha/year. Dutch farms produced $70 \%$ more milk/ha but had $\mathrm{N}$ inputs of $568 \mathrm{~kg} / \mathrm{ha}, \mathrm{N}$ outputs in produce of $81 \mathrm{~kg} / \mathrm{ha}$ (14\% efficiency) and a $\mathrm{N}$ surplus of $487 \mathrm{~kg} / \mathrm{ha}$. English farms were intermediate. In the DRC farmlets, applying fertiliser $\mathrm{N}$ at $400 \mathrm{~kg} \mathrm{~N} /$ ha/year increased $\mathrm{N}$ surpluses and nitrate leaching by $3-4$ fold, resulting in nitrate- $\mathrm{N}$ concentrations in drainage of $2.5 \times$ the recommended maximum for drinking water. The most efficient farm system received no $\mathrm{N}$ fertiliser and was highly stocked (3.3 Friesian cows/ha) for very high pasture utilisation. This resulted in similar milk production/ha to Dutch farms (with $1 / 3$ the $\mathrm{N}$ inputs) and a $45 \%$ efficiency of conversion of $\mathrm{N}$ inputs from $\mathrm{N}_{2}$ fixation into milk and meat products.
\end{abstract}

Keywords: dairy farm, nitrate leaching, nitrogen balance, nitrogen fertiliser, stocking rate

\section{Introduction}

Increased intensity of dairy farming and greater nitrogen (N) fertiliser use have raised questions about the implications to the environment. In the European Union, the main environmental concern of intensive dairy farming is the losses of $\mathrm{N}$, particularly by nitrate leaching into groundwater. This concern has led to several countries introducing mandatory nutrient accounting on farms, with emphasis on N. In The Netherlands, this nutrient accounting is being selected as a procedure to control nutrient use and to tax nutrient surpluses
(Breembroek et al. 1996).

Dairying in The Netherlands has been characterised by a marked increase in inputs of purchased feed and $\mathrm{N}$ fertiliser. By mid 1980s, an "average" Dutch dairy farm on sandy soils used over $7 \mathrm{t} / \mathrm{ha}$ of concentrates or maize silage and applied $330 \mathrm{~kg} \mathrm{~N} / \mathrm{ha} /$ year (Aarts et al. 1992). In New Zealand, there has been a trend for increasing use of supplements and fertiliser $\mathrm{N}$, although at much lower levels to that in The Netherlands (current average of approximately $0.3 \mathrm{t} \mathrm{DM} / \mathrm{ha} /$ year in purchased feed and $40 \mathrm{~kg} \mathrm{~N} / \mathrm{ha} /$ year; B. Atrill \& T. Johnston pers. comm.). Current research at DRC Number 2 dairy has been examining the effects of increased inputs of $\mathrm{N}$ fertiliser and supplementary feed on farm productivity and profitability (Penno et al. 1996).

This paper presents $\mathrm{N}$ balances for "average" dairy farms in New Zealand, south west England and The Netherlands, and for farmlets at DRC Number 2 dairy. It also describes the extent of $\mathrm{N}$ losses from the DRC farmlets with varying $\mathrm{N}$ fertiliser use and stocking rates.

\section{Methods}

\section{Calculation of $\mathbf{N}$ balances}

$\mathrm{N}$ balances are a method of summarising $\mathrm{N}$ inputs and outputs from a farm system. The $\mathrm{N}$ balance for an "average" New Zealand dairy farm was estimated using data from the Livestock Improvement dairy statistics 1995-1996. Production data from farmlets at DRC Number 2 dairy for 1993-1997 were used to construct $\mathrm{N}$ balances for farmlets varying in rate of $\mathrm{N}$ fertiliser application, supplementary feeding and stocking rate. Published data were used for summarising $\mathrm{N}$ balances on dairy farms in south west England (Jarvis 1993) and The Netherlands (Aarts et al. 1992).

\section{Farmlet experiment}

In June 1993, a farmlet trial was established at DRC Number 2 dairy, Hamilton (Penno et al. 1996), which included five farmlets. Three farmlets have been stocked at 3.3 cows/ha and have received nominal rates of $\mathrm{N}$ fertiliser of 0,200 or $400 \mathrm{~kg} \mathrm{~N} / \mathrm{ha} /$ year. Two farmlets had $4.4 \mathrm{cows} / \mathrm{ha}$ (low and high stocking rates are subsequently described by subscripts $\mathrm{L}$ or $\mathrm{H}$ ), and received 200 or $400 \mathrm{~kg} \mathrm{~N} / \mathrm{ha} /$ year. The last two farmlets also used crushed maize grain at approximately $1 \mathrm{t} /$ 
cow/year, although this ceased in the third year on the $400 \mathrm{~N}_{\mathrm{H}}$ farmlet. Pastures were predominantly perennial ryegrass and white clover.

Milk volume and protein content were measured weekly for each farmlet. $\mathrm{N}$ transfer from paddocks to the lanes and milking shed via cow excreta was determined by visual assessment of dung and urine deposition.

Detailed measurements of $\mathrm{N}_{2}$ fixation and $\mathrm{N}$ losses were made on the $0,200 \mathrm{~N}_{\mathrm{L}}, 400 \mathrm{~N}_{\mathrm{L}}$ and $400 \mathrm{~N}_{\mathrm{H}}$ farmlets and were confined to four replicate paddocks on a free-draining ash soil (yellow-brown loam; Umbric Dystrochrept). Details of methods were described by Ledgard et al. (1996). In brief, $\mathrm{N}_{2}$ fixation by white clover was determined by ${ }^{15} \mathrm{~N}$ isotope dilution, and measurements of $\mathrm{N}$ loss were ammonia volatilisation (by a mass balance micrometeorological method), denitrification (using acetylene inhibition) and nitrate leaching (using ceramic cup samplers in conjunction with lysimeters). Data for the first 3 years of the study are presented.

\section{Results}

\section{$\mathbf{N}$ balances on commercial farms}

Milk production/ha on the "average" Dutch farm was $70 \%$ higher than that on the "average" New Zealand farm. This was achieved with 3.1-fold higher $\mathrm{N}$ inputs and a 3.7-fold higher $\mathrm{N}$ surplus (Table 1). Milk production, $\mathrm{N}$ inputs and $\mathrm{N}$ surplus on farms in south west England were intermediate between those on New Zealand and Dutch farms. Farms differed greatly in the forms of $\mathrm{N}$ input, $\mathrm{N}_{2}$ fixation predominating in New Zealand and $\mathrm{N}$ fertiliser being the main $\mathrm{N}$ input on Dutch and English farms. Dutch farms also had a large $\mathrm{N}$ input in purchased feed.

\section{$\mathrm{N}$ balances and losses from DRC farmlets}

Increased $\mathrm{N}$ fertiliser and maize grain inputs increased milk production/ha by up to $58 \%$ (Table 2). This was associated with an increase in $\mathrm{N}$ inputs of up to 2.9-fold and an increased $\mathrm{N}$ surplus of up to 4 -fold. The type of input had a large effect on the efficiency of $\mathrm{N}$ use. The two farmlets received $\mathrm{N}$ fertiliser at $400 \mathrm{~kg} \mathrm{~N} / \mathrm{ha} /$ year had the highest $\mathrm{N}$ inputs and $\mathrm{N}$ surpluses. The highest-producing farmlet $\left(200 \mathrm{~N}_{\mathrm{H}}\right)$ received $\mathrm{N}$ fertiliser at $200 \mathrm{~kg} \mathrm{~N} / \mathrm{ha} /$ year and maize grain at $4480 \mathrm{~kg} \mathrm{DM} / \mathrm{ha} / \mathrm{year}$, and was intermediate in its $\mathrm{N}$ input and $\mathrm{N}$ surplus.
Table 1 Farm characteristics and estimates of $\mathrm{N}$ inputs and outputs ( $\mathrm{kg} / \mathrm{ha} /$ year) for average dairy farms in New Zealand, south west England, and in The Netherlands on sandy soils.

\begin{tabular}{lccc}
\hline & $\begin{array}{c}\text { New Zealand } \\
(1995-96)\end{array}$ & $\begin{array}{c}\text { SW England } \\
(1991)\end{array}$ & $\begin{array}{c}\text { The Netherlands } \\
(1983-1988)\end{array}$ \\
\hline Farm size (ha) & 82 & 76 & 25 \\
Cows/ha & 2.4 & 2.2 & 2.3 \\
Milk (litres/cow) & 3182 & 5554 & 5737 \\
Total milk (litres/ha) & 7360 & 12219 & 13195 \\
Nitrogen inputs & & & \\
Fertilisers & 40 & 250 & 331 \\
N2 fixation & 140 & 10 & 0 \\
Purchased feed & 4 & 52 & 181 \\
Atmospheric deposition & 2 & 25 & 48 \\
Miscellaneous & 0 & 0 & 8 \\
Total N inputs & $\mathbf{1 8 6}$ & $\mathbf{3 3 7}$ & $\mathbf{5 6 8}$ \\
Nitrogen output in products & & & \\
Milk & 47 & 39 & 67 \\
Meat & 8 & 28 & 14 \\
Total N output & $\mathbf{5 5}$ & $\mathbf{6 7}$ & $\mathbf{8 1}$ \\
Nitrogen surplus & $\mathbf{1 3 1}$ & $\mathbf{2 7 0}$ & $\mathbf{4 8 7}$ \\
N outputs/N inputs & $30 \%$ & $20 \%$ & $14 \%$ \\
\hline
\end{tabular}

${ }^{1}$ Based on assumed pasture production of $13 \mathrm{t} \mathrm{DM} / \mathrm{ha} /$ year, $17 \%$ clover and results from past studies on $\mathrm{N}$ concentration and proportion of $\mathrm{N}$ fixed.

Table 2 Milk production and estimates of $\mathrm{N}$ inputs and outputs ( $\mathrm{kg}$ $\mathrm{N} /$ ha/year) for dairy farmlets varying in $\mathrm{N}$ fertiliser application (nominally 0,200 or $400 \mathrm{~kg} \mathrm{~N} /$ ha/year) and stocking rate $(L=3.3$ cows $/$ ha, $H=4.4$ cows $/$ ha). Data are the mean of 3 years.

\begin{tabular}{lcccccc}
\hline & $0 \mathrm{~N}_{\mathrm{L}}$ & $200 \mathrm{~N}_{\mathrm{L}}$ & $400 \mathrm{~N}_{\mathrm{L}}$ & $400 \mathrm{~N}_{\mathrm{H}}$ & $200 \mathrm{~N}_{\mathrm{H}}$ & $\mathrm{SED}$ \\
\hline Cows/ha & 3.3 & 3.3 & 3.3 & 4.4 & 4.4 & \\
Milk (litres/cow) & 3953 & 4735 & 4858 & 4410 & 4592 & \\
Total milk (litres/ha) & 12955 & 15516 & 15921 & 19653 & 20466 & \\
$\mathrm{~N}$ inputs & & & & & & \\
$\quad$ Fertiliser & 0 & 215 & 413 & 411 & 213 & \\
$\quad \mathrm{~N}_{2}$ fixation & 174 & 117 & 40 & 37 & 117 & 15 \\
Purchased feed & 3 & 4 & 3 & 58 & 101 & \\
Atmospheric deposition & 2 & 2 & 2 & 2 & 2 & \\
$\quad$ Total N inputs & $\mathbf{1 7 9}$ & $\mathbf{3 3 8}$ & $\mathbf{4 5 8}$ & $\mathbf{5 0 8}$ & $\mathbf{4 3 3}$ & \\
N output in products & & & & & & \\
$\quad$ Milk & 75 & 89 & 92 & 113 & 121 & \\
Meat & 6 & 6 & 6 & 9 & 9 & \\
Surplus silage & 0 & 15 & 28 & 5 & 0 & \\
Total N output & $\mathbf{8 1}$ & $\mathbf{1 1 0}$ & $\mathbf{1 2 6}$ & $\mathbf{1 2 7}$ & $\mathbf{1 3 0}$ & \\
Nitrogen surplus & $\mathbf{9 7}$ & $\mathbf{2 2 8}$ & $\mathbf{3 3 2}$ & $\mathbf{4 0 1}$ & $\mathbf{3 0 3}$ & \\
$\quad$ N outputs/N inputs & $45 \%$ & $33 \%$ & $28 \%$ & $25 \%$ & $30 \%$ & \\
Nitrogen losses/removals & & & & & & \\
$\quad$ Denitrification & 5 & 17 & 25 & 24 & & 4 \\
Volatilisation & 15 & 41 & 65 & 68 & & 6 \\
Leaching & 40 & 81 & 152 & 136 & & 24 \\
Transfer to lanes/sheds & 57 & 78 & 84 & 85 & & \\
Total N outputs+losses & 198 & 327 & 452 & 440 & & \\
Nitrogen balance & -19 & +11 & +6 & +68 & & \\
\hline & & & & & & \\
\hline
\end{tabular}


Gaseous N losses were relatively small, although both denitrification and volatilisation increased by approximately 5-fold between the $0 \mathrm{~N}$ and $400 \mathrm{~N}$ farmlets. Nitrate leaching was a major $\mathrm{N}$ loss process and increased to high levels in the $400 \mathrm{~N}$ farmlets. Approximately $15 \%$ of the excreta $\mathrm{N}$ was transferred to lanes and the milking shed, with most to the latter. This was collected and pumped to oxidation ponds, and therefore represented a loss of $\mathrm{N}$ from the farmlets. The total $\mathrm{N}$ inputs were equivalent to total $\mathrm{N}$ outputs, bearing in mind the experimental error in determining the various components.

\section{Discussion}

\section{Milk production and $\mathrm{N}$ inputs}

Commercial farms in New Zealand and overseas had a lower level of milk production/ha over a range of $\mathrm{N}$ inputs than the farmlets at DRC Number 2 dairy (Figure 1a), which could be attributed to the greater pasture production and_utilisation in the farmlets. This is evident from the much higher stocking rates in the DRC farmlets, although per cow production was lower than in the Dutch and English systems (Tables 1,2). Milk production/ha from the $0 \mathrm{~N}$ farmlet was similar to that for the Dutch and English dairy farms, even though the latter had 2- to 3-fold higher $\mathrm{N}$ inputs.

On the DRC farmlets stocked at 3.3 cows/ha, increasing $\mathrm{N}$ fertiliser application from 0 to $400 \mathrm{~kg}$ $\mathrm{N} /$ ha/year increased milk production by $23 \%$ and most of this increase (20\%) had occurred with $200 \mathrm{~kg} \mathrm{~N} / \mathrm{ha} /$ year. Increasing the stocking rate to $4.4 \mathrm{cows} / \mathrm{ha}$ at the $400 \mathrm{~N}$ rate increased milk production/ha by a further $5 \%$ (Penno unpublished). Including maize grain in the cows' diet at the high stocking rate, in conjunction with $200 \mathrm{~kg} \mathrm{~N} / \mathrm{ha} / \mathrm{year}$, led to the largest increase in milk production $(+58 \%$ over $0 \mathrm{~N})$. Economic analyses (based on 1995 milk prices and $47 \mathrm{c} / \mathrm{kg}$ maize grain) indicated that the $200 \mathrm{~N}_{\mathrm{L}}$ farmlet was the most profitable, although its Economic Farm Surplus was only $\$ 66 /$ ha $(+2.7 \%$ ) ahead of the $0 \mathrm{~N}$ farmlet (Penno et al. 1996). Use of lower rates of $\mathrm{N}$ fertiliser (e.g., $100 \mathrm{~kg} \mathrm{~N} / \mathrm{ha} /$ year) applied strategically for defined feed shortages is likely to be more profitable per unit $\mathrm{N}$ than the 200 or $400 \mathrm{~N}$ rates (e.g., Ledgard et al. 1994).

$\mathrm{N}$ inputs in the $0 \mathrm{~N}$ farmlet were almost entirely from $\mathrm{N}_{2}$ fixation by white clover, and varied between 100 and $230 \mathrm{~kg} \mathrm{~N} / \mathrm{ha} /$ year. Applying N fertiliser at 400 $\mathrm{kg} \mathrm{N} / \mathrm{ha} /$ year decreased $\mathrm{N}_{2}$ fixation to low levels (15$60 \mathrm{~kg} \mathrm{~N} / \mathrm{ha} /$ year), owing to a large reduction in clover growth and to clover substituting fertiliser $\mathrm{N}$ uptake for $\mathrm{N}_{2}$ fixation.

\section{$\mathrm{N}$ outputs and losses}

Figure 1 Relationship between total $\mathrm{N}$ inputs and (a) milk production or (b) $\mathrm{N}$ surplus (i.e., $\mathrm{N}$ inputs $-\mathrm{N}$ outputs in milk+meat) for a range of farm systems. Triangles refer to "average" farms and squares to DRC farmlets, with numbers representing $N$ fertiliser application ( $\mathrm{kg} \mathrm{N} / \mathrm{ha} / \mathrm{year}$ ) and letters being stocking rate ( $L=3.3$ cows $/$ ha, $H=4.4$ cows $/ \mathrm{ha}$ ).

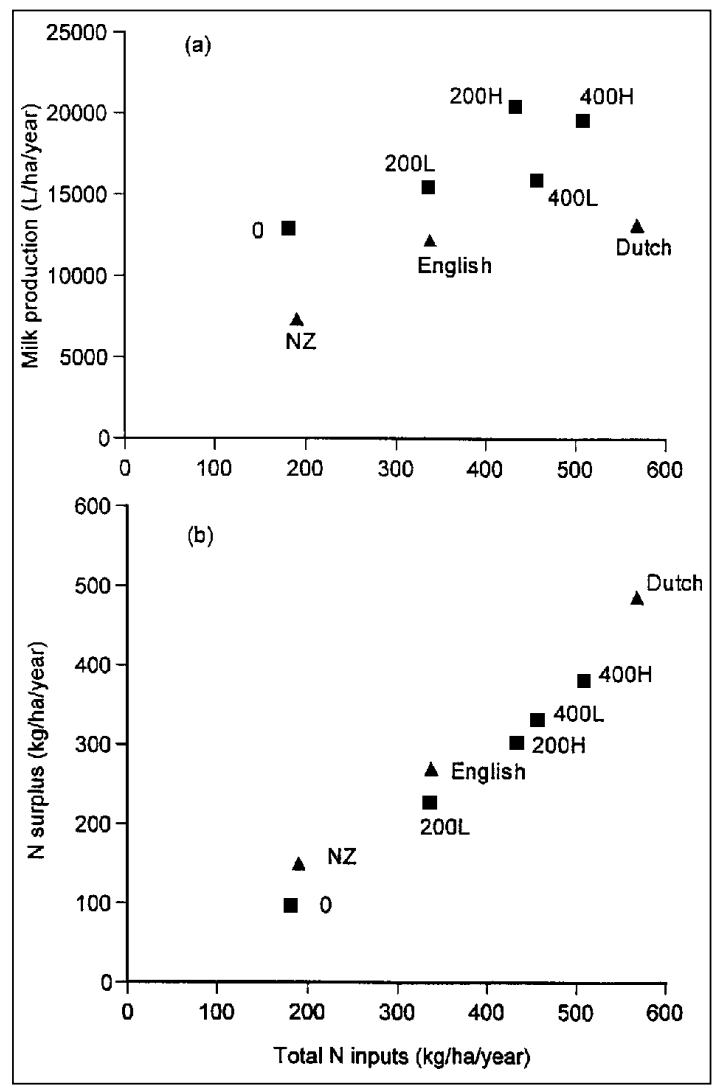

$\mathrm{N}$ outputs in produce generally increased with increasing $\mathrm{N}$ inputs. However, the $\mathrm{N}$ outputs in produce were the same for the $0 \mathrm{~N}$ farmlet and the average Dutch farm despite much higher $\mathrm{N}$ inputs in the latter.

The difference between $\mathrm{N}$ inputs and $\mathrm{N}$ outputs in products is the $\mathrm{N}$ surplus, and this was linearly related to the $\mathrm{N}$ input levels (Figure 1b). Detailed measurements in the DRC farmlet study indicated that the $\mathrm{N}$ surplus was transferred or lost from the paddocks. Transfer of excreta- $\mathrm{N}$ to lanes and the milking shed showed a small increase with increasing $\mathrm{N}$ inputs, whereas gaseous and leaching losses all increased by approximately 4-fold between the 0 and $400 \mathrm{~N}$ farmlets. The main environmental concern is from nitrate leaching to groundwater and analyses of the water draining through these soils showed average nitrate-N concentrations of 6,13 and 
$27 \mathrm{mg} / \mathrm{litre}$ in the 0,200 and $400 \mathrm{~N}_{\mathrm{L}}$ farmlets, respectively. Similar concentrations were measured in the groundwater. Thus, drainage water from the $400 \mathrm{~N}$ farmlet had nitrate-N concentrations well above the recommended maximum for drinking water of $11.3 \mathrm{mg} /$ litre (Ministry of Health 1995). Associated studies indicated that the main source of leached $\mathrm{N}$ was from cow urine (Ledgard et al. 1996), leaching occurring during the period of net drainage (predominantly June-September).

A reduction in $\mathrm{N}$ losses to the environment could be achieved by decreasing $\mathrm{N}$ inputs, reducing levels of potentially-leached $\mathrm{N}$ in soil in late-autumn-winter, or increasing feed-N utilisation by cows. Options for reducing potentially leached $\mathrm{N}$ include avoiding $\mathrm{N}$ fertiliser application in late-autumn-winter (when growth responses are slow and direct leaching losses can occur), and using "grazing-off" strategies during this period (e.g., using feed pads with effluent collection for redistribution in spring-summer). Improving feed $\mathrm{N}$ utilisation by cows through conversion into milk reduces the $\mathrm{N}$ susceptible to loss.

\section{$\mathrm{N}$ utilisation efficiency}

The efficiency of conversion of pasture (and maize) $\mathrm{N}$ consumed by dairy cows into milk and meat averaged $14.9,14.0,13.5,16.6$ and $15.9 \%$ in the $0 \mathrm{~N}, 200 \mathrm{~N}_{\mathrm{L}}$, $400 \mathrm{~N}_{\mathrm{L}}, 200 \mathrm{~N}_{\mathrm{H}}$ and $400 \mathrm{~N}_{\mathrm{H}}$ farmlets, respectively. Thus, $\mathrm{N}$ fertiliser application reduced the efficiency of $\mathrm{N}$ utilisation whereas maize supplementation increased it. Maize represents a high energy feed with a low $\mathrm{N}$ concentration (e.g., $1.5 \% \mathrm{~N}$ compared to c. $4 \%$ for $\mathrm{N}$-boosted pasture). This has the additional benefit of increasing $\mathrm{N}$ excretion in dung relative to urine and reducing possible $\mathrm{N}$ losses. Potentially, $\mathrm{N}$ use efficiency could also be increased through plant breeding and management practices to lower the plant $\mathrm{N}$ concentration or manipulate other plant characteristics to increase amino acid absorption (Van Vuuren \& Meijs 1987). The maximum theoretical utilisation of dietary $\mathrm{N}$ is $40-45 \%$ (Van Vuuren \& Meijs 1987).

Despite the relatively low efficiency of $\mathrm{N}$ utilisation from pasture consumed by cows, the overall farm conversion of total $\mathrm{N}$ inputs to $\mathrm{N}$ output in products was high in the $0 \mathrm{~N}$ farmlet at $45 \%$. This apparent contrast was owing to the efficient recycling of $\mathrm{N}$ within the grazed pasture system, as evidenced by total annual $\mathrm{N}$ uptake in pasture herbage at $543 \mathrm{~kg} \mathrm{~N} / \mathrm{ha}$ relative to the annual $\mathrm{N}$ input of $181 \mathrm{~kg} \mathrm{~N} / \mathrm{ha} / \mathrm{year}$. The high pasture utilisation by cows (about 90\%) in the $0 \mathrm{~N}$ farmlet also favoured high milk production, so that the $\mathrm{N}$ output in milk was $60 \%$ greater than on an average New Zealand farm even though both systems had a similar total $\mathrm{N}$ input.

The $\mathrm{N}$ output/input ratio decreased greatly to $25-$
$32 \%$ in the $\mathrm{N}$-fertilised farmlets and was only $14 \%$ in the intensive Dutch farms. Current research in The Netherlands is examining practices to increase $\mathrm{N}$ recovery in milk to about $30 \%$ by reducing stocking rate, reducing $\mathrm{N}$ fertiliser use, growing more maize, better matching feed demands with concentrate supply, and improved storage and application of slurry (Aarts et al. 1992). This would coincide with a reduction in $\mathrm{N}$ surplus from $480 \mathrm{~kg} \mathrm{~N} / \mathrm{ha} /$ year to about $200 \mathrm{~kg} \mathrm{~N} / \mathrm{ha} /$ year and thereby markedly reduce the potential for $\mathrm{N}$ loss. Some of these practices could also be used on more intensive moderate-high $\mathrm{N}$ input farms in New Zealand to reduce $\mathrm{N}$ losses. However, achieving $\mathrm{N}$ losses below that in the $0 \mathrm{~N}$ farmlet would be difficult without significant changes to management and costs, e.g., substituting some pasture for maize silage, or use of a feed pad system to reduce excreta return in late-autumnwinter.

\section{Conclusions}

Increasing $\mathrm{N}$ inputs on dairy farms increased $\mathrm{N}$ surpluses and led to relatively large increases in gaseous losses and nitrate leaching. Applying N fertiliser at $400 \mathrm{~kg} \mathrm{~N} /$ ha/year was less efficient than $200 \mathrm{~kg} \mathrm{~N} / \mathrm{ha} /$ year + maize supplementation at increasing milk production and $\mathrm{N}$ off-take, and high rates of $\mathrm{N}$ application had an adverse effect on groundwater nitrate levels. The most efficient farm system used no $\mathrm{N}$ fertiliser, had an $\mathrm{N}$ surplus of only $100 \mathrm{~kg} \mathrm{~N} / \mathrm{ha} /$ year, and a high stocking rate which resulted in similar production per ha to the Dutch farms and a very high $(45 \%)$ conversion of $\mathrm{N}$ inputs from $\mathrm{N}_{2}$ fixation into milk.

\section{ACKNOWLEDGEMENTS}

We thank Kevin Macdonald, Wally Carter and staff for trial conduct; George Brier, Ernest Nemaia, Li Ouyang and Gordon Rajendram for sample collection and analysis; and the Foundation for Research Science and Technology for funding this research.

\section{REFERENCES}

Aarts, H.F.M.; Biewinga, E.E.; Van Keulen, H. 1992. Dairy farming systems based on efficient nutrient management. Netherlands journal of agricultural science 40: 285-299.

Breembroek, J.A.; Koole, B.; Poppe, K.J.; Wossink, G.A.A. 1996. Environmental farm accounting: The case of the Dutch nutrients accounting system. Agricultural systems 51: 29-40.

Jarvis, S.C. 1993. Nitrogen cycling and losses from dairy farms. Soil use and management 9: 99-105. 
Ledgard, S.F.; Clark, D.A.; Sprosen, M.S.; Brier, G.J.; Nemaia, E.K.K. 1996. Nitrogen losses from grazed dairy pasture, as affected by nitrogen fertiliser application. Proceedings of the New Zealand Grassland Association 57: 21-25.

Ledgard, S.F.; Crush, J.R.; Roberts, A.H.C.; O'Connor, M.B. 1994. Nitrogen fertiliser, clover and the environment. Proceedings of the Large Herds Conference 25: 48-53.

Ministry of Health. 1995. Drinking water standards for
New Zealand. Ministry of Health, Wellington: 187.

Penno, J.W.; Macdonald, K.A.; Bryant, A.M. 1996. The economics of No 2 dairy systems. Proceedings of the Ruakura Farmers' Conference 48: 11-19.

Van Vuuren, A.M.; Meijs, J.A.C. 1987. Effects of herbage composition and supplement feeding on the excretion of nitrogen in dung and urine by grazing dairy cows. In Animal Manure and Fodder Crops. Eds. Van der Meer, H.G. et al. pp. 17-25. Martinus Nijhoff Publishers, Dordrecht. 
